\title{
INFINITE STRIVING AND THE INFINITE SUBJECT: A KIERKEGAARDIAN REPLY TO SCHELLENBERG
}

\author{
JEFFREY HANSON \\ Harvard University
}

\begin{abstract}
In this paper I argue - pace J. L. Schellenberg - that it remains the case for Kierkegaard that infinite striving, properly understood, is essential to the relationship with God, who remains the Infinite Subject, one necessarily hidden for defensible logical, ontological, and existential reasons. Thus Kierkegaard's arguments for the hiddenness of God as a logically required ingredient in the relationship that human beings are called to undertake with God can withstand Schellenberg's criticisms.
\end{abstract}

The influence of J. L. Schellenberg's Divine Hiddenness and Human Reason has been far-reaching, perhaps even transformative of the contemporary scene in philosophy of religion. Among the many potential objectors he treats, Schellenberg seems to have a proverbial soft spot for Søren Kierkegaard.

Schellenberg's account of the Dane's viewpoint, which is brief and overly reliant on idiosyncratic interpreters like Louis Pojman and Robert Adams, who advance oddly literalistic and highly contestable views, is prefaced by his sketch of a Kierkegaardian picture of subjectivity. Following that sketch, the main part of Schellenberg's recapitulation of Kierkegaard explains how hiddenness according to the Dane has both a positive function to stimulate the striving and passion definitive of subjectivity and a negative function to militate against the self-deceived complacency that would inevitably result if the subject imagined God could be related to objectively, as if God were merely another object in the world. Of course ultimately Schellenberg argues that Kierkegaard's arguments do not amount to an actual rebuttal.

Nevertheless, Schellenberg admits Kierkegaard is perhaps the most formidable opponent of his view. While his treatment of Kierkegaard 
is respectful, it does not include some crucial elements of the Dane's thought that if properly understood will give persons interested in the issue of divine hiddenness further reason to explore Kierkegaard's thought as a resource against Schellenberg's version of the argument.

When discussing Kierkegaard, Schellenberg concentrates his criticism on premise (6) of what he calls (somewhat prejudicially) the Deception Argument, so this paper will present two rejoinders that defend the soundness of premise (6) against Schellenberg.

Recall that premise (6) reads: "If strong, objective evidence of God's existence were made available to them, human beings would form (false) beliefs entailing that subjectivity is of no great importance."' The reason this premise is important is that the remainder of a key argument that Schellenberg attributes to Kierkegaard rests upon it. From this premise it is a short distance to the conclusion that "if strong, objective evidence of God's existence were made available to them, human beings would not become subjective," ${ }^{2}$ a crucial failing on Kierkegaard's view. Because people are generally indisposed to become the single individual standing alone before God, to become the self that they can only be by achieving the highest possible relationship of which human beings are capable, the relationship with the divine, then Kierkegaard can argue that a certain amount of striving is required to attain the ideal for humanity, a striving that divine obviousness would render unnecessary.

Interestingly Schellenberg gives quite a bit of credit to Kierkegaard. With respect to what he has called the Stimulus Argument, which supports the positive work of inciting human beings to seek out the hidden God, Schellenberg concedes that Kierkegaard's version is an improvement on Pascal's and admits further that "Kierkegaard can claim that faith ... logically requires Divine hiddenness: if we accept his concept of faith at all, we ipso facto accept the necessity of Divine hiddenness for its instantiation." ${ }^{3}$ Similarly, when summarizing what he has called the Deception Argument, which supports the negative task of defeating

${ }^{1}$ J. L. Schellenberg, Divine Hiddenness and Human Reason, $1^{\text {st }}$ edition (Ithaca: Cornell University Press, 2006), 164-65. Admittedly this paper addresses only Schellenberg's arguments in this book, which opened a debate that has continued since, and Schellenberg himself has advanced his own continued refinements and improvements to his thinking in the years since its initial publication. He has, however, not returned to sustained discussion of Kierkegaard's arguments, so this paper engages only that limited topic.

${ }^{2}$ Ibid., 165.

${ }^{3}$ Ibid., 158. 
the possibility that human beings could acquire false beliefs about God and thus lapse into complacency if God were not elusive, Schellenberg again admits that Kierkegaard's "arguments do indeed provide possible rebuttals for the prima facie case we are considering, for each suggests that God has reason not to put his existence beyond reasonable nonbelief for all human beings at all times." It seems to me then that Schellenberg gives more ground to Kierkegaard than to any of his other interlocutors, and a defense of Kierkegaard then could have outsized impact on the success of Schellenberg's argument. I thus concentrate in what follows on responding to Schellenberg's arguments that Kierkegaard's claims ultimately fail.

The first reason Schellenberg claims that they fail is because Kierkegaardian faith cannot be plausibly viewed as an outweighing or offsetting good. ${ }^{5}$ I do not think that Kierkegaard would claim that faith was an outweighing or offsetting good of the sort that Schellenberg describes. Not because Kierkegaard does not think faith is supremely important - clearly it is - but because a necessary condition of attaining Kierkegaardian faith is that one refuse the crude calculus of "outweighing" and "offsetting" that Schellenberg depends upon.

For Kierkegaard, faith is an attitude that transforms the whole of the believer's life and relationship to others and to her experience. The passionate concern of faith is not for the quantitatively maximally great good available but for God and for the believer's eternal happiness at rest in God, which is the absolutely great good, which is to say, it is qualitatively higher than any other available good. If we remain only with the Concluding Unscientific Postscript, the only work of Kierkegaard's that Schellenberg deals with in any detail, we find its pseudonymous author, Johannes Climacus, making this very point:

An eternal happiness relates itself with pathos to an essentially existing person, not to a speaker who is courteous enough to include it on the list of the good things for which he supplicates. Usually people abhor denying that such a good exists; so they include it but, just by including $i t$, show that they do not include it. I do not know whether one should laugh or weep on hearing the enumeration: a good job, a beautiful wife, health, the rank of a councilor of justice - and in addition an eternal happiness, which is the same as assuming that the kingdom of heaven

\footnotetext{
${ }^{4}$ Ibid., 161-162.

${ }^{5}$ Ibid., 162.
} 
is a kingdom along with all the other kingdoms on earth and that one would look for information about it in a geography book. ${ }^{6}$

Kierkegaard's claim about the value of passionate faith then is not that it outweighs or offsets competing goods but rather precisely that no such comparison between the absolute good and relative goods is possible.

By the same logic, we can respond to Schellenberg's objection that "it is hard ... to see why such an intense form of inwardness should be idealized ... Such intensity seems too narrow, excluding as it does many other good things in life which a loving God might wish us to experience and enjoy." This again is a misreading, and it is a great misfortune that Schellenberg cites at this point not Kierkegaard himself but Robert Adams, from an essay published 40 years ago. ${ }^{8}$ Adams again mistakenly imagines that what Johannes Climacus means by an infinite passion or interest is a quantitative maximum, such that the life of religious faith becomes one of grossly irresponsible risk-taking. On Adams's and Schellenberg's caricature of Kierkegaard, the faithful person deliberately seeks out as many states of affairs to be uncertain about as possible and then flings herself indiscriminately and with reckless abandon at the slightest vanishing hope. Adams sniffs in disapproval that "in a tolerable religious ethics some way must be found to conceive of the religious interest as inclusive rather than exclusive of the best of other interests." Indeed. Fortunately, this is exactly Kierkegaard's view.

Not only is religious passion not one passion among others, and its object not one among others, but as absolute the eternal happiness found in God alone and the faithful person's infinite passion for it is inclusive of other goods. The best example I can use comes from Fear and Trembling, in a passage where Kierkegaard's pseudonymous persona, Johannes de Silentio, asserts that God demands "absolute love" but immediately clarifies by saying

Anyone who in demanding a person's love believes that this love is demonstrated by his becoming indifferent to what he otherwise cherished is not merely an egotist but is also stupid... For example,

${ }^{6}$ Concluding Unscientific Postscript to Philosophical Fragments, vol. 1, tr. Howard V. and Edna H. Hong (Princeton, NJ: Princeton University Press, 1992), 391.

${ }^{7}$ Divine Hiddenness and Human Reason, 162.

8 Robert M. Adams, "Kierkegaard's Arguments against Objective Reasoning in Religion," The Monist 60 (1976), 228-243.

${ }^{9}$ Quoted at Divine Hiddenness and Human Reason, 163. 
a man requires his wife to leave her father and mother, but if he considers it a demonstration of her extraordinary love to him that she for his sake became an indifferent and lax daughter etc., then he is far more stupid than the stupid. If he had any idea of what love is, he would wish to discover that she was perfect in her love as a daughter and sister, and he would see therein that she would love him more than anyone in the kingdom. ${ }^{10}$

The point of this example I trust cuts directly against Schellenberg and Adams. God is not a jealous, possessive, and abusive husband who confiscates all our other interests and loves in favor of his own exclusive enjoyment. When Kierkegaard speaks of absolute love he means a love that is not exhaustive but transformative. Far from enjoining a monomaniacal intensity, Kierkegaard's God insists on fidelity to other responsibilities. Indeed, I would go further and suggest that the absolute love of the believer for her God impels her to redoubled energies in her loves for others and cultivations of diverse passions and projects. This redoubling in fact would itself be evidence of the absolute nature of her primary devotion. To stick with de Silentios example of marriage, the participants in the absolute relationship of the marriage partnership are prepared to take delight not just in the love that each has for the other but in the general expansiveness of love as it is shared preeminently of course in the marriage but by extension to others as well. Neither God nor a loving husband wants single-minded devotion that inhibits other goods and their pursuit but wants the full flourishing of the beloved, a prize that can only be won if the primary love relationship doesn't stifle other loves and passions but in point of fact provokes them in turn to even more profound intensification.

The mistake that Schellenberg and Adams make is to assume that love is a zero-sum game. On their mistaken premise that passion has to be apportioned out from limited supplies into a narrow range of potential channels, a possessive bullying posture - whether from the divine or from a human so-called lover - is almost inevitable. If love is finite, if each of us has so much passion that we are forced by scarcity to expend parsimoniously, then of course in order to convince me that you really love me I need to see you stop loving someone else, as if love shared with them is automatically not love shared with me.

${ }^{10}$ Fear and Trembling, tr. Howard V. and Edna H. Hong (Princeton, NJ: Princeton University Press, 1983), 73. 
But obviously the experience of the truly mutually devoted couple exposes this mistake for what it is; there is not only so much love to go around. Love is infinite and expansive; the more it is shared the more there is to share. Surely this is the only right way to represent the divinity, not as a jealous control freak. So if God demands absolute love, and it would seem to be the case that God indeed does, it is demanded in such a way as to result in the expansion of love generally, both empowering lovers to love and enabling the reciprocation of love.

On this point I am seconding and extending an argument already made by M. Jamie Ferreira, who has identified a significant problem with Schellenberg's critique of Kierkegaard, namely, that he seems to think Kierkegaard is making a psychological claim about the motivation of belief, when in fact the claim is based on the grammar of the absolute. ${ }^{11}$ The hiddenness of God is for Kierkegaard not a psychological stimulus to the would-be believer but an inherent ingredient in what Kierkegaard means when he speaks of God as absolute.

Ferreira identifies this problem as a critical error on Schellenberg's part, since this confusion mistakes an important ontological point for a merely psychological description; the latter is easier to dismiss, the former harder to overcome. This paper seeks to expand upon Ferreira's claim, for its legitimacy is not merely confined to the Concluding Unscientific Postscript (the one text she focuses on in her rejoinder to Schellenberg) nor is it restricted to the issues she concentrates on.

To widen the scope of the grammar of absoluteness, and its implications, it is necessary to reject the fundamental starting point of Schellenberg's argument, which he reminds his readers in the preface to the paperback edition, is "reflection on Divine love." ${ }^{2}$ For the Kierkegaardian viewpoint this paper seeks to develop, there can be no a priori reflection on divine love, because we do not know what divine love entails. On the contrary, the revelation of divine love as it is provided in Scripture often involves the most shocking reversals and upsetting of seemingly plausible basic principles. Perhaps nowhere are these dynamics more conspicuously in view than in the "hard sayings" of Jesus

${ }^{11}$ M. Jamie Ferreira, "A Kierkegaardian View of Divine Hiddenness," in Divine Hiddenness: New Essays, ed. Daniel Howard-Synder and Paul K. Moser (Cambridge, UK: Cambridge University Press, 2002), 164-180. See especially 165, 169-70.

12 Divine Hiddenness and Human Reason, viii. 
in the Gospels, which enjoin hatred of family, division, self-mutilation, and other apparent horrors in the name of love. On my reading of the celebrated and controversial teleological suspension of the ethical from Fear and Trembling, the entire point of this conceptual move is to mark the limits of humanly constructed visions of what the good life would consist in.

Yet Schellenberg seems to have in mind another concern. As I read him, his objection is that Kierkegaard seems to call for wholesale devotion to risk and sacrifice, to a life without reward or consolation of any kind, offered madly to an unresponsive deity. He may (as Ferreira seems to think) be interrogating what seems to be Kierkegaard's assumption that intensity of pursuit must match extremity of object, but it seems to me that the concern is somewhat more straightforward, namely, that such a life of risk and sacrifice is simply inhuman and puritanically self-denying. In place of what he seems to perceive as overly rigid austerity, Schellenberg suggests that "a life of gradual development and transformation, involving risks and sacrifices but other goods as well ... seems to more nearly conform to the Christian ideal." 13

Once again, however, this is not a point against Kierkegaard but a confirmation of his very thinking. For support I need avert only to the justly famous portrait of an imagined contemporary knight or hero of faith conjured by Johannes de Silentio in Fear and Trembling. According to this crucially important image, the most striking thing about the hero of faith walking the streets of Copenhagen is that there is nothing striking about him at all. He looks more like a tax collector than a saint, he takes pleasure in everything around him, even the most pedestrian goings-on, and most important of all, he gives no evidence of being particularly religious. Over a lengthy two-page description the only observation that Silentio makes about the knight of faith's overt religiosity is that he goes to church and sings lustily. Yet this person he insists is the perfect picture of someone who is living the life of faith. Indeed the stereotype of the Christian believer as a mirthless and unworldly self-flagellator could not be further from Kierkegaard's mind. It is no mistake that throughout the Concluding Unscientific Postscript Climacus militates against monasticism as an ersatz Christianity, a failure to live Christianly in the world in favor of a blameworthy retreat from the everyday and all

${ }^{13}$ Divine Hiddenness and Human Reason, 163. 
the pleasures and pains that belong to the quotidian, from the small to great. ${ }^{14}$

It is just such a life of fullness and embrace that Kierkegaard commends as entirely characteristic of faith, the passion that plumbs depths unsuspected by acting merely "as if" there were a God, which is the depleted position that Schellenberg claims is Kierkegaard's last available recourse and a redoubt that cannot be preferred to the state of affairs that Schellenberg calls belief. This is certainly true; acting "as if" there were a God when one knows intellectually that there is not (or at least knows that there is no reason to think there is a God) is not a course of action Kierkegaard would commend. But again, Schellenberg misunderstands a basic point of Kierkegaardian epistemology. Like many other readers of Kierkegaard, he seems to think that the Dane advocates a kind of choice whereby one decides "against all odds,"15 that the point is to will against countervailing evidence. It would be more accurate to say however that for Kierkegaard choice is what terminates reflection, which left unchecked is an in-principle endless process. Particularly when it comes to decisions that demand passion, where an ethical or religious issue is at stake, the decision involves not so much settling on the pros or settling on the cons but setting aside the business of tallying pros and cons altogether.

Consider again Kierkegaard's favorite sort of example, marriage. I can reflect on whether or not I should marry Person X and gather information on the subject of marriage from married persons, I can read books about how to have a successful marriage and so forth, I can make a long list of pros about Person X's attractive and admirable qualities and an equally long list of cons about the annoying and imperfect things about Person X, but none of this is fully determinative for what I decide about what to do with Person X, whether to marry or not. A decision to marry might look naively like deciding that the pros outweigh the cons; by the same logic, a decision not to marry might look naively like deciding that the cons outweigh the pros. But I think Kierkegaard's view on this is that in either case I have decided - with the assistance of course

\footnotetext{
${ }^{14}$ Fear and Trembling, 38-40.

${ }^{15}$ Divine Hiddenness and Human Reason, 155. Even some more sympathetic and wellinformed readers make this error. See Andrew Cross, "Fear and Trembling's Unorthodox Ideal," Philosophical Topics 27.2 (1999): 227-53, 237; see also John Lippitt, Routledge Philosophy Guidebook to Kierkegaard and Fear and Trembling (London: Routledge, 2003). 70, 71, 75.
} 
of careful reflection - but I have decided and to decide means to regard reflection's assistance as being at an end. If I decide to marry Person X to be at all sensible I have to acknowledge for instance that there is a chance that Person X will hurt me very deeply, that they will betray my trust. If I decide to marry Person $\mathrm{X}$ in view of that possibility, then we would never say I am deciding "against all odds." Instead I am not playing the odds anymore; I recognize that there are risks, and I accept them. This is why after all we pledge to marry until death parts us; it's a salient and sober reminder that the person to whom you are committing yourself will in fact die, and so no marriage has a proverbial "happy ending." We don't delude ourselves into thinking we are avoiding the "cons;" instead we accept the cons with pros, for richer or poorer, in sickness and health. That's not acting "as if" we are really loving or being loved in return; that's believing in the face of objective uncertainties.

Once again a qualitative change of attitude is called for by Kierkegaard. Interestingly Vigilius Haufniensis, Kierkegaard's pseudonymous author of The Concept of Anxiety, directly juxtaposes the faithful person with the inveterate gambler, who is the true type of the person who resolves "against all odds." The committed gambler in his view is never completely disabused; she plays on believing, holding out hope for the one time fate will smile on her, and recognizing that loss is part of the nature of the game; she won't walk away from the table, no matter how deeply she sinks into debt. For her, wedded to fortune as she is, loss and gain don't matter. When all is fate, then the next turn of the card could always reverse her fortunes. By contrast, the faithful person rests not stoically in fate but joyfully in the arms of providence. This is not a change of perspective on some particular set of experiences but a reorientation of posture toward actuality itself. To be a believer in providence though is to reinterpret the ups and downs of life not as the inscrutable vagaries of fate but as the dispensations of a loving power at work in my life, bringing even evils to a good issue. The faithful person doesn't choose against the odds; she doesn't play the odds at all. ${ }^{16}$

As an expansion of this basic epistemological point, I would further indicate that from Kierkegaard's perspective, the situation with respect to evidence is in a way rather more dire even than Schellenberg recognizes. At this stage in the argument he thinks the best Kierkegaard can do

16 The Concept of Anxiety, ed. and trans. Reidar Thomte (Princeton, NJ: Princeton University Press, 1980), 159-62. 
is put on an act in the face of insufficient evidence, but according to Kierkegaard all evidence is radically ambivalent. Because of this faith is always twinned by doubt, which in Kierkegaard's estimation of its best practitioners, has something very definitely in common with faith; both attitudes are what he would call "second immediacies," not spontaneous uncontrollable feelings but acquired passions, and both take up a posture toward the whole of experience where both the doubter and believer have to acknowledge that that very experience is unpredictably correlated to their respective postures. In short, for Kierkegaard, a person could survey the whole of experience and conclude that life is an endlessly variegated tapestry of beauty and joy obviously bequeathed to us by an infinitely loving and gracious creator and with as much reason conclude that life is a sustained horror show of pain and despair inflicted on us by a sadistic cosmic bungler. Further reflection on either side of this basic argument has little power to either reinforce or diminish doubt or faith, both of which are controlling attitudes that dictate how we reflect on evidence rather than products of reflection on uninflected evidence. Contrary to Schellenberg's caricature of the faithful person as one who doggedly sticks to her beliefs in the face of overwhelming defeating evidence, it is the fatalist who according to Kierkegaard can never be disabused, no matter how many losses she suffers. The fatalist, like a committed gambler, is always ready to play again in the barest hope of a hollow victory.

It is on this basis that I would respond to Schellenberg's appeal to specifically "religious evidence," which he claims could supply what is missing if objective evidence is to be denied us on the basis of the need to establish a right relationship between the human being and the deity. $\mathrm{He}$ writes, "we must once again stress that religious experience could provide the necessary evidence, and that, so far from leading to the formation of beliefs entailing that subjectivity is of no importance, such experience could inspire subjectivity" ${ }^{17}$

This is unfortunately question begging on the face of it. Appealing to religious evidence will hardly solve the problem when what is already precisely in question is what sort of evidence counts as "religious," that is, sufficiently convincing to establish the existence of God. What Schellenberg seems to mean by religious experience is whatever experience would be adequate to establish the existence of God, which in circular fashion is itself required for the possibility of having religious experience.

${ }_{17}$ Divine Hiddenness and Human Reason, 166. 
Leaving that aside, I think Kierkegaard would in a way agree: It is quite possible that our experience can lead us to deeper awareness of God and appreciation of who God is and thereby inspire deeper subjectivity. One thinks most readily of Abraham's experience of readiness to sacrifice his son Isaac and, far more important, his expectation that he will receive him back again. One of the central insights offered by de Silentio is that Abraham does what he does both for God's sake and for his own, which he claims amount to the same thing. ${ }^{18}$ So of course Abraham acts in response to the hidden God's demand, but he also receives a restored and deepened relationship with that very God, whose character is disclosed more fully as a result of what takes place on Mount Moriah. One of the central insights afforded by Abraham's harrowing encounter is that, as he puts it, "The Lord will provide." This seems to be true even when we don't know how it could be true or in what form God's provision could present itself. It is for this reason that faithful confidence in God's provision probably cannot be grounded to the degree that Schellenberg seems to think is required, having set the bar quite high indeed.

But just because God is hidden to some extent doesn't mean we get nothing for all our striving. Kierkegaard's writings are full of examples, like Abraham, who indeed attains a higher level of subjectivity thanks to his faith, or like the merman, also in Fear and Trembling, who transforms his life in response to the invincible innocence of Agnes, or the maiden in Philosophical Fragments who wins the joy of loving, and being loved by, the king. Kierkegaard was fond of the gospel of Matthew, and he remarks on the parable found there of the rich young ruler that "that rich young man should have given away everything, but if he had done so, then the knight of faith would have said to him: By virtue of the absurd, you will get every penny back again - believe it!"19 Definitive of faith in fact is not sacrifice but reward. Sacrifice is perfectly within the sphere of capability for stoics and pagans and despairing persons according to Kierkegaard. What makes faith faith is not readiness to sacrifice but expectation of receiving everything back again. Admittedly this happens in a transformed way, and again in ways we cannot predict, but it is overwhelmingly clear from reading Fear and Trembling alone if nothing else, that experiential evidence is available to the believer, who has her reward, a reward the world of objectivity cannot supply.

${ }^{18}$ Fear and Trembling, 59.

${ }^{19}$ Ibid., 49. 
The world of objectivity cannot supply such a reward for two reasons: first, God as the Infinite Subject can never fully appear in the world of objectivity. For this reason Climacus quips that "True inwardness does not demand any sign at all in externals;" ${ }^{20}$ second, to relate to God as the Infinite Subject demands that we do so in a manner ultimately incommensurate with the manner by which we relate to objective truths.

Much of what Schellenberg has to say against Kierkegaard misses the mark because he does not take on board a remark from Kierkegaard's journals that Christianity is not a doctrine but an "existentialcommunication." ${ }^{21}$ The sort of striving then that Kierkegaard commends is not finally a striving toward greater conceptual clarity but a striving to be like Christ. As Sylvia Walsh helpfully clarifies, "To say that Christianity is not a doctrine is not, however, to deny that it has doctrines but only to insist that it is not to be identified with them or with an objective understanding of them." 22 It is precisely this objective understanding however that Schellenberg constantly tries to ground, a project that Kierkegaard would say is of limited value in the first place. Schellenberg is right though that "if the God met in experience is the infinite Subject of Kierkegaard's writings, there will be no end to the process of 'coming to know God' even for the one who has believed from the start." ${ }^{23}$ This is true but only if the process of coming to know God is fundamentally different from the interminable process by which we try to gain exhaustive objective knowledge of some content or doctrine. The process of coming to know God however is one of personal transformation, as I become more like God, an ongoing and limitless task of sanctification that requires some intellectual understanding of what Christianity teaches to be sure ${ }^{24}$ but cannot be reduced to that intellectual understanding. Climacus most emphatically of the pseudonymous authors militates against the notion

\footnotetext{
${ }^{20}$ Concluding Unscientific Postscript, 414.

${ }^{21}$ Søren Kierkegaard's Journals and Papers, ed. and tr. Howard V. and Edna H. Hong (Bloomington, IN: Indiana University Press, 1967-78), 484.

${ }^{22}$ Walsh, Sylvia, "Kierkegaard's Theology," in The Oxford Handbook of Kierkegaard, ed. John Lippitt and George Pattison (Oxford, UK: Oxford University Press, 2013), 293.

${ }^{23}$ Divine Hiddenness and Human Reason, 167.

${ }^{24}$ Again see Walsh: "Yet Climacus also maintains that if one is a Christian one must know what Christianity is and be able to say what it is by comparing it with one's earlier life when one was not a Christian" (293) and again, "For Climacus, and presumably for Kierkegaard also, one can know what Christianity is without being a Christian, but one cannot be a Christian without knowing what Christianity is" (283).
} 
that one can "approximate" truthful living as a Christian in the same sense that a group of scientists can articulate more and more clearly the truth of their theory about, say, the natural world. Because of the insurmountable distinction between objective and subjective truth, the truth-conducive procedures of scientific inquiries for example, or historical research, cannot be applied to subjective concerns with the legitimate hope of yielding the same reliable results.

No one has explained this more clearly perhaps than M. G. Piety, whose brief treatment of the subject in her essay "The Epistemology of the Postscript" has the added benefit of explaining how (and this is a point long overlooked by Kierkegaard commentators who have not appreciated a terminological distinction in Kierkegaard's Danish) a believing person might approach subjective truth by living it out. As Piety writes, "According to Kierkegaard, however, ethical and religious prescriptions are actualized by an individual, not in the sense that his 'historical externality' is made to correspond to them, but in the sense that he has truly willed such correspondence. To agree with the substance of ethical and religious prescriptions is to make a conscious, or inward, effort to bring one's existence into conformity with them." ${ }^{25}$ Though such a process is necessarily unfinished for an existent self always in becoming, the demand to so bring one's existence into conformity is not thereby diminished, and the resulting conformity can, as Piety makes clear, be deemed a kind of approximation, though of a different kind from the approximation attained by ever greater certainty in scientific or historical investigation. In the case of ethical or religious truths, "one has no guarantee that the apparent probability of the correspondence of a particular statement about actuality to the reality to which it refers is objectively vindicated - in the sense that, the more probable the correspondence appears, the closer he is to its absolute determination. That is, an increase in the apparently probability of the correspondence brings the subject no closer to establishing genuine correspondence."26

I conclude then by asserting that it remains the case for Kierkegaard that infinite striving, properly understood, is essential to the relationship with God, who remains the Infinite Subject, one necessarily hidden for

${ }^{25}$ M. G. Piety, “The Epistemology of the Postscript," in Kierkegaard's Concluding Unscientific Postscript: A Critical Guide, ed. Rick Anthony Furtak (Cambridge, UK: Cambridge University Press, 2010), 201.

${ }^{26}$ Ibid., 200. 
defensible logical, ontological, and existential reasons. Schellenberg is to be congratulated for forcing a more articulate and careful elaboration of these reasons, but Kierkegaard's arguments for the hiddenness of God as a logically required ingredient in the relationship that human beings are called to undertake with God can withstand his criticisms. 